\title{
PENGARUH NILAI TAMBAH PRODUKSI DAN JASA LOGISTIK PADA VOLUME EKSPOR PRODUK TEKSTIL DI JAWA TENGAH
}

\author{
Kurniani', Yusmar Ardhi Hidayat, Achmad Zaenuddin, Suwardi \\ Jurusan Administrasi Bisnis, Politeknik Negeri Semarang, Semarang, Indonesia \\ email: ${ }^{1}$ kurniani2301@gmail.com
}

\begin{abstract}
This research purposes to analyze the impact of production added value from textile industries and logistic service to textile export value in Central Java. The secondary data used are an export statistic and regional domestic product total, and logistics service between 2010 and 2017. The result shows that, first, production added value has negatively influence to textile export value. Second, logistic service has a positive effect on export value. It implies that textile export value may result in order demand. In addition, logistics service has the main role to boost up textile export.
\end{abstract}

Keywords: Production, Added Value, Logistic, Textile Export and Central Java.

\section{PENGARUH NILAI TAMBAH PRODUKSI DAN JASA LOGISTIK PADA VOLUME EKSPOR PRODUK TEKSTIL DI JAWA TENGAH}

\begin{abstract}
Abstrak
Penelitian ini bertujuan untuk menganalisis pengaruh nilai tambah produksi dan jasa logistik terhadap nilai eksport produk tekstil di Jawa Tengah. Data sekunder digunakan adalah Produk Domestik Regional Bruto dan Statistik Ekspor mulai tahun 2010 sampai 2017. Hasil diperoleh bahwa nilai tambah produksi justru berpengaruh negative terhadap nilai ekspor produk tekstil. Jasa logistik berpengaruh positif terhadap nilai ekspor. Hal ini mengindikasikan nilai ekspor tekstil merupakan bagian dari permintaan. Layanan logistik berperan meningkatkan ekspor tekstil.
\end{abstract}

Keywords:Produksi, Nilai Tambah, Logistik, Ekspor Tekstil, dan Jawa Tengah

\section{PENDAHULUAN}

Penelitian tentang faktor-faktor yang mempengaruhi volume ekspor tekstil dan produk tekstil telah banyak dilakukan peneliti seperti Yulyanti (2002), Chintia (2008), Khairunnisa dan Septi (2009), Nugroho (2011), Setianto W (2014) dengan pendekatan teori permintaan produk yang menggunakan variabel-variabel makroekonomi seperti harga produk ekspor, kurs, GDP dan kondisi perekonomian dunia. Hal yang membedakan penelitian ini dengan penelitian sebelumnya adalah analisis volume ekspor dari sisi teori produksi dan dukungan multimodal transportasi dari sisi subsektor transportasi (logistik) dan ketersediaan moda transportasi laut. Dilihat dari sisi aktivitas multimodal transportasi, pengiriman ekspor didukung dari aktivitas transportasi dan ketersediaan kapal yang datang di pelabuhan.

Volume ekspor tekstil dan produk tekstil yang dianalisis di wilayah Jawa Tengah karena merupakan pusat perusahaan tekstil yang mendapatkan fasilitas kawasan berikat dimana industri tekstil dan produk tekstil ini mendapatkan pembebasan bea masuk impor bahan baku kapas dan hasil produksinya wajib diekspor, disertai dengan pengawasan 
yang cukup ketat dari petugas bea dan cukai. Selain fasilitas, volume ekspor tekstil dan produk dari tekstil ini merupakan hasil dari penciptaan nilai tambah produksi dari pengolahan bahan baku menjadi produk tekstil jadi. Hal yang menarik adalah sebagian besar produksi tekstil ini merupakan permintaan pesanan (derived demand) dari mitra importir yang sudah memiliki hubungan subsidiary dan kontrak jangka panjang. Selain pemberian fasilitas dan derived demand, produsen tekstil dan produk dari tekstil memberikan nilai tambah barang dari sisi penciptaan nilai tambah produksi.

Selain dari sisi produksi, volume ekspor tekstil dipengaruhi sektor transportasi dan pengangkutan (logistik) untuk mengirimkan dari gudang eksportir ke pelabuhan dengan syarat produk ekspor sudah terpenuhi penyelesaian eksportasi pabeannya. Rangkaian proses pengriman ekspor juga melibatkan ketersediaan moda transportasi laut. Kontrak pengiriman yang disepakati antara eksportir dan importir yang memiliki keuntungan dan resiko di tengah-tengah adalah Free on Board (FOB) dengan titik penyerahan kewajiban penyerahan produk ekspor di atas kapal.

Sektor transportasi (logistik) yang menjadi urat nadi pengiriman ekspor di Jawa Tengah sedang mengalami stagnasi pembangunan karena pemerintah sedang memprioritaskan pembangunan jalur transportasi di luar Pulau Jawa. Krisis ekonomi 2008 juga mempengaruhi kenaikan harga bahan baku tekstil sehingga menyebabkan nilai tambah produksi tekstil menurun yang berdampak pada fluktusasi penurunan nilai ekspor tekstil dan produk dari tekstil.

Produk ekspor impor yang ditangani dalam proses bongkar muat di Jawa Tengah sebagian besar berasal dari daerah Kabupaten Semarang, Kabupaten Jepara, Kota Semarang, dan Kabupaten Pekalongan. Adapun komoditas yang diekspor sebagian besar furniture dan tekstil (Pelindo III, 2015).

Tujuan penelitian ini adalah :
1. Menganalisis pengaruh nilai tambah produksi terhadap volume ekspor tekstil dan produk tekstil di Jawa Tengah.

2. Menganalisis pengaruh transportasi pada volume ekspor tekstil dan produk tekstil di Jawa Tengah.

Tinjauan Pustaka

Teori yang dapat digunakan untuk menganalisis hubungan sektor logistik dan ekspor adalah:

a. Teori Basis Ekonomi

Teori basis ekonomi menyatakan bahwa faktor penentu utama pertumbuhan ekonomi suatu daerah adalah berhubungan langsung dengan permintaan akan barang dan jasa dari luar daerah. Pertumbuhan industri yang menggunakan sumberdaya lokal, tenagakerja, dan bahan baku untuk diekspor akan menghasilkan kekayaan daerah dan menciptakan peluang kerja. (Lincolin Arsyad,1999)

Pemerintah daerah menekankan pentingya kegiatan perdagangan yang memiliki pasar nasional atau internasional dan membantu industri basis ekspor. Pemerintah dapat mengurangi hambatan ekspor industri dengan memberikan pengurangan pajak, menyediakan fasilitas transportasi, dan komunikasi untuk mendukung industri berbasis ekspor (Blakely, 1989)

\section{b. Teori Neo Klasik}

Teori neoklasik tidak menekankan keseimbangan dan mobilitas faktor produksi (Lincolin Arsyad,1999). Proses penyesuaian ke tingkat keseimbangan pertumbuhan terjadi karena didukung fasilitas perhubungan dan komunikasi. (Syafrizal,1983)

\section{c. Teori Lokasi}

Ahli ekonomi regional berpendapat pengaruh penting dalam pertumbuhan ekonomi daerah adalah lokasi. Perusahaan cenderung untuk meminimalkan biaya dengan memilih lokasi yang dapat memaksimalkan kesempatan berdekatan dengan pasar. Industri/perusahaan akan memilih lokasi terbaik yang memiliki 
biaya minimal transportasi hubungan antara sumber bahan mentah dan pasar. (Blakely, 1989)

Manajemen Logistik

Manajemen logistik menurut Bowersox et. al (2002) adalah: "Proses pengelolaan yang strategis terhadap pemindahan dan penyimpanan barang, sukucadang dan barang jadi dari para supplier, diantara fasilitasfasilitas perusahaan dan kepada para langganan"

Tujuan logistik menurut Bowersox et. al (2002) adalah menyampaikan barang jadi dan bermacam-macam material dalam jumlah yang tepat pada waktu dibutuhkan, dalam keadaan yang dapat dipakai, ke lokasi dimana dibutuhkan, dan dengan total biaya yang terendah.

Ada 5 komponen yang bergabung untuk membentuk systemlogistic: yaitustruktur lokasi fasilitas, transportasi, persediaan (inventory), komunikasi, penanganan (handling) dan penyimpanan (storage).

\section{METODE PENELITIAN}

Variabel dan Definis Operasional Variabel Penelitian

Tabel 1. Variabel dan Definisi Operasional

\begin{tabular}{lllll}
\hline No & Variabel & Definisi Operasional & Satuan & Jenis Data \\
\hline 1 & Nilai Tambah & $\begin{array}{l}\text { Nilai produksi sektor transportasi dan } \\
\text { pergudangan setahun tercatat dalam Produk } \\
\text { Logistik }\end{array}$ & $\begin{array}{l}\text { Jutaan } \\
\text { Rupiah }\end{array}$ & Rasio \\
2 & $\begin{array}{l}\text { Nilai Tambah } \\
\text { Produksi }\end{array}$ & $\begin{array}{l}\text { Nilai tambah produksi industi tekstil dan } \\
\text { pakaian jadi setahun yang tercatat pada } \\
\text { Produk Domestik Regional Bruto di Jawa } \\
\text { Tengah }\end{array}$ & $\begin{array}{l}\text { Jutaan } \\
\text { Rupiah }\end{array}$ & Rasio \\
3 & Nilai Ekspor Tekstil & $\begin{array}{l}\text { Nilai ekspor produk benang dan industri } \\
\text { tekstil setahun dari Jawa Tengah }\end{array}$ & Dollar & Rasio \\
\hline
\end{tabular}

Data dan Sumber Data

Data yang digunakan adalah data sekunder yang diperoleh dari Data BPS dengan periode tahun 2010 - 2017. Data yang digunakan adalah nilai tambah transportasi, nilai tambah produksi tekstil dan nilai ekspor tekstil di Jawa Tengah.

\section{Alat Analisis}

Alat analisis yang digunakan adalah statistik deskriptif dan regresi berganda. Statistik deskriptif digunakan untuk menganalisis data time series. Sedangkan, persamaan regresi berganda digunakan untuk menganalisis hubungan pengaruh antara variabel-variabel independen terhadap variabel dependen. Model persamaan regresi penelitian akan diuji terlebih dahulu menurut asumsi klasik uji normalitas, multikoliniearitas, heterokedastisitas, dan autokorelasi.

\section{HASIL DAN PEMBAHASAN}

Ekspor Impor Jawa Tengah

Jawa Tengah (Jateng) merupakan salah satu Propinsi di Jawa, terletak diantara dua Propinsi besar, yaitu Jawa Barat dan Jawa Timur. Jateng terletak di $5^{\circ} 40^{\prime}$ dan $8^{\circ} 30^{\prime}$ Lintang Selatan dan antara $108^{\circ} 30^{\prime}$ dan $111^{\circ} 30^{\prime}$ Bujur Timur (termasuk Pulau Karimunjawa). Jarak terjauh dari Barat ke Timur adalah $263 \mathrm{Km}$ sedangkan jarak dari Utara ke Selatan $226 \mathrm{Km}$ (tidak termasuk pulau Karimunjawa).

Propinsi Jateng secara admistratif terbagi menjadi 29 Kabupaten dan 6 Kota. Wilayah Jateng seluas 3,25 juta hektar atau sekitar 25,04 persen dari luas pulau Jawa $(1,70$ persen luas Indonesia). Luas terdiri dari 1,00 juta hektar (30,80 persen) lahan sawah dan 2,25 juta hektar $(69,20$ persen) bukan lahan sawah. 
Kurniani, dkk/AdBis 20 (1): 11 - 20

Tabel 2.Total Ekspor Migas dan Non Migas Jawa TengahTahun 2016 - 2017

\begin{tabular}{lllll}
\hline \multirow{2}{*}{ Ekspor } & \multicolumn{2}{c}{ Nilai FOB (Juta US \$) } & Perubahan & Share 2017 \\
\cline { 2 - 3 } & Tahun 2016 & Tahun 2017 & & \\
\cline { 1 - 2 } Migas & 113,47 & 223,93 & 97,35 & 3,74 \\
Non-Migas & 5275,73 & 5767,44 & 9,32 & 96,26 \\
Jumlah & 5389,20 & 5991,37 & 11,17 & 100,00 \\
\hline
\end{tabular}

Sumber :BPS Jateng (2018) diolah.

Total nilai ekspor Jawa Tengah tahun 2017 tercatat sebesar US\$ 5991,37 juta; terdiri dari ekspor non migas sebesar US\$ 5767,44 juta dan ekspormigas sebesar US\$223,93 juta. Bila dibandingkan dengan total ekspor JawaTengah tahun 2016 yang mencapai US\$ 5 389,20 juta, terlihat adanyakenaikan sebesar 11,17 persen. Dalam kondisi demikian nilai ekspor non migas naik 9,32 persen, sedangkan ekspor migas naik sebesar 97,35 persen. Peranan komoditas non migas terhadap total ekspor Jawa Tengah mencapai 96,26 persen, sedangkan komoditas migas sebesar 3,74 persen.

Berdasarkan informasi nilai ekspor per kelompok komoditas, pada Tabel 2, dapat diketahui komoditas komoditas yang menjadi potensi unggulan ekspor dari JawaTengah. Pada tahun 2017 kelompok komoditas yang mendominasi eksporJawa Tengah adalah kelompok komoditas benang dan industri tekstil (05)yang nilainya mencapai US\$2,53 milyar dengan kontribusi sebesar 42,31 persenterhadap total nilai ekspor Jawa Tengah. Ekspor komoditas benang dan industri tekstil(05) mengalami kenaikan sebesar 8,47 persen dibanding ekspor tahun 2016. KelompokKomoditas Industri Kayu, Gabus \& Jerami (06) menempati urutan kedua dengan nilaiekspor US\$ 969,54 juta, mengalami kenaikan 1,47 persen dibanding ekspor tahun 2016,dengan kontribusi terhadap total ekspor sebesar 16,18 persen. Selanjutnya, nilai eksporkelompok komoditas Industri Lainnya (16) menempati urutan ke tiga besar dengan nilaiekspor tercatat sebesar US\$ 675,97 juta dengan peranan sebesar 11,28 persenterhadap ekspor total Jawa Tengah, turun 1,91 persen dibanding nilai ekspor tahun2016 (US\$ 689,11 juta).

Tabel 3. Nilai (FOB) \& Persentase Kelompok Komoditas Ekspor Jateng Tahun 2016 \& 2017 (Juta US\$)

\begin{tabular}{|c|c|c|c|c|c|}
\hline \multirow[t]{2}{*}{ No } & \multirow[t]{2}{*}{ Kelompok Komoditas } & \multicolumn{2}{|c|}{ Nilai FOB(Juta US \$) } & \multirow{2}{*}{$\begin{array}{l}\text { Kontribusi } \\
2017\end{array}$} & \multirow[t]{2}{*}{ Pertumbuhan } \\
\hline & & 2016 & 2017 & & \\
\hline 1 & Peternakan & 83,06 & 155,87 & 2,60 & 87,65 \\
\hline 2 & Pertanian \& Kehutanan & 211,60 & 225,81 & 3,77 & 6,72 \\
\hline 3 & Pertambangan \& Penggalian & 21,64 & 17,86 & 0,30 & $-17,44$ \\
\hline 4 & Industri Makanan, Minuman \& Tembakau & 181,13 & 141,60 & 2,36 & $-21,82$ \\
\hline 5 & Benang \& Industri Tekstil & 2336,98 & 2534,94 & 42,31 & 8,47 \\
\hline 6 & Industri Kayu, Gabus \& Jerami & 955,51 & 969,54 & 16,18 & 1,47 \\
\hline 7 & Industri Kertas & 56,54 & 73,61 & 1,23 & 30,19 \\
\hline 8 & Kulit dan Industri Kulit & 29,68 & 47,62 & 0,79 & 60,44 \\
\hline 9 & Industri Kimia, Plastik \& Karet & 264,10 & 299,48 & 5,00 & 13,39 \\
\hline 10 & BBM & 113,47 & 223,93 & 3,74 & 97,35 \\
\hline 11 & Perlengkapan Pribadi & 51,15 & 186,52 & 3,11 & 264,65 \\
\hline 12 & Industri Mineral \& Batuan & 55,28 & 44,49 & 0,74 & $-19,52$ \\
\hline 13 & Industri Logam & 31,75 & 30,68 & 0,51 & $-3,37$ \\
\hline 14 & Industri Mesin, Listrik \& Elektr. & 306,48 & 361,51 & 6,03 & 17,96 \\
\hline 15 & Kendaraan dan Spare-part & 1,72 & 1,93 & 0,03 & 12,31 \\
\hline \multirow[t]{2}{*}{16} & Industri Lainnya & 689,11 & 675,97 & 11,28 & $-1,91$ \\
\hline & Jumlah & 5389,20 & 5991,37 & 100 & 11,17 \\
\hline
\end{tabular}

Sumber :BPS Jateng (2018) diolah. 
Dibandingkan kondisi tahun 2016, urutan kelompok komoditas berdasarkan nilai ekspor terbesar tidak mengalami perubahan urutan yang berarti. Hal ini mencerminkan kondisi ekspor Jawa Tengah tahun 2017 masih relatif sama dengantahun kinerja ekspor Jawa Tengah pada tahun 2016. Persentase perubahan nilai eksportahun 2017 dibanding 2016 per kelompok komoditas dapat dilihat pada tabel 3.

\section{Hasil Pengolahan}

Hasil pengoahan analisis regresi ditampilkan pada tabel 4.

Tabel 4. Hasil Pengolahan Regresi Berganda

\begin{tabular}{lllll}
\hline Variabel & Koefisien & Std. Error & t-Statistic & Sig. \\
\hline Contanta & 6,53 & 2,018 & 3,222 & 0,023 \\
Ln $\left(\mathrm{X}_{1}\right)$ & $-0,009$ & 0,041 & $-0,213$ & 0,840 \\
Ln $\left(\mathrm{X}_{2}\right)$ & 0,890 & 0,101 & 0,9661 & 0,000 \\
\hline R-squared & 0,942 & Mean Square Regression & 0,085 \\
Adjusted R-squared & 0,919 & Mean Square Residual & 0,1906 \\
S.E. of regression & 0,0457 & F-statistic & 40,660 \\
Sum squared resid & 0,010 & Prob(F-statistic) & 0.001 \\
Durbin-Watson stat & 3,048 & & \\
\hline
\end{tabular}

Sumber :BPS Jateng (2018) diolah.

Model Persamaan Regresi ditulis sebagai berikut.

Ln Y $=\mathrm{c}-0,009 \operatorname{Ln} \quad \mathrm{X}_{1}+0,890 \operatorname{Ln} \mathrm{X}_{2}+\varepsilon$ Alfa yang digunakan dalam pengujian model ini $5 \%$.

\section{Normalitas}

Pengujian normalitas dilakukan dengan melihat grafik histogram normalitas di grafik 1, terlihat data yang digunakan membentuk lonceng yang simetris kanan kiri yang menunjukkan data berdistribusi normal.

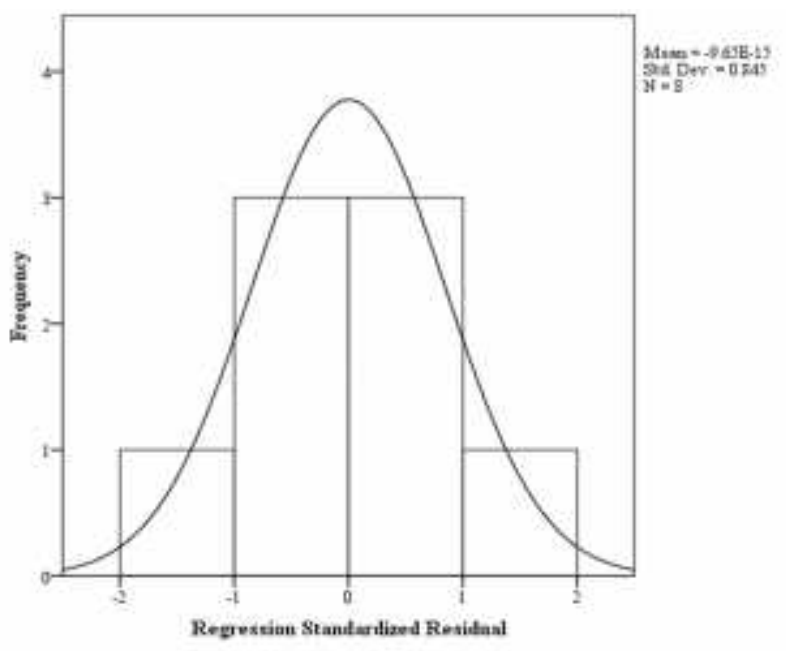

Grafik1. Distribusi Normalitas Residual Persamaan Regresi

Uji Asumsi Klasik

Ujia asumsi klasik digunakan untuk membuktikan bahwa variabel-variabel independen yang digunakan mampu mempengaruhi variabel dependen secara baik sesuai dengan teori digunakan. Uji asumsi klasik dideteksi adanya multikolinieritas, heterokedastisitas, dan autokorelasi. Pendeteksian uji asumsi klasik diawali dengan deteksi multikolinieritas di bawah ini.

Multikolinearitas 
Deteksi multikolinieritas dilakukan untuk mendeteksi hubungan korelasi antar variabel independen yang digunakan dalam model regresi. Jika terdapat korelasi yang kuat antar variabel independen akan menyebabkan variabel independen tidak berpengaruh terhadap variabel dependen. Deteksi hubungan korelasi antara variabel ( X1) dan $\mathrm{X} 2$ dengan melihat nilai VIF pada tabel 5 .

Tabel 5. Covariance Matrik

\begin{tabular}{ccc}
\hline Variabel & Covariance & VIF \\
\hline $\mathrm{X}_{1}, \mathrm{X}_{2}$ & 0,965 & 1.036 \\
\hline
\end{tabular}

Sumber :BPS Jateng (2018) diolah.

Nilai yang digunakan sebagai acuan untuk mendeteksi multikolinieritas antar variabel adalah nilai VIF (Variance-Inflating Factor) yang diperoleh dari nilai covariance data antara variabel-variabel independen yang digunakan. Jika tidak terdapat hubungan korelasi antara variabel-variabel independen, maka nilai VIF sama dengan 1 . Jika nilai VIF naik lebih dari 10 maka ada indikasi korelasi kuat antar variabel independen yang digunakan (Gudjarati, 2009. p:328). Nilai VIF sama dengan 1,036 yang berarti tidak terdapat hubungan korelasi antar variabel independen dalam model ini. Uji asumsi selanjutnya adalah uji heterokedastisitas nilai residual.

\section{Heterokedastisitas}

Model regresi yang baik mampu memprediksi hubungan antara variabel independen dengan variabel dependen dengan tepat sehingga nilai residual-residual memiliki variance yang sama bahkan mendekati nol. Uji heterokedatisitas digunakan uji gejser dengan meregres variabel $\mathrm{X}_{1}$ dan $\mathrm{X} 2$ terhadap residual. $\mathrm{U}^{2}=\mathrm{c}+0,009 \mathrm{Ln} \quad \mathrm{X}_{1}+0,890 \mathrm{Ln}$ $\mathrm{X}_{2}+\varepsilon$

Tabel 6. Hasil Uji Gejser

\begin{tabular}{|c|c|c|c|c|c|}
\hline \multirow[t]{2}{*}{ Variabel } & \multicolumn{2}{|c|}{ Unstandardized Coefficients } & \multirow{2}{*}{$\begin{array}{c}\text { Standardized } \\
\text { Coefficients } \\
\text { Beta }\end{array}$} & \multirow[t]{2}{*}{$\mathrm{t}$} & \multirow[t]{2}{*}{ Sig. } \\
\hline & B & Std. Error & & & \\
\hline Constanta & .154 & .086 & & 1.796 & .132 \\
\hline Pertambahan Produksi Tekstil & .000 & .002 & -.040 & -.120 & .909 \\
\hline Transportasi dan Pergudangan & -.009 & .004 & -.684 & -2.042 & .097 \\
\hline
\end{tabular}

Sumber :BPS Jateng (2018) diolah.

Hasilnya menunjukkan bahwa semua variabel independen tidak berpengaruh terhadap residual sehingga persaman regresi memiliki asumsi homokedastisitas.

\section{Uji Autokorelasi}

Autokrelasi digunakan untuk menguji apakah distribusi residual memiliki nilai acak dan tidak membentuk pola hubungan korelasi residual positif atau negatif sehingga model regresi mampu memprediksi pengaruh variabel independen pada variabel dependen secara tepat dan signifikan. Hasil pengolahan regresi memperoleh nilai Durbin-Watson stat 3,048 , kemudian variabel independen yang digunakan 2(k) dengan jumlah sampel data 24 maka nilai berdasarkan tabel Durbin Watson yaitu $\mathrm{dl}=1,118$ dan $\mathrm{du}=1,546$. Kriteria pengujian deteksi autokorelasi disajikan berikut ini. 
Tabel 7. Pengujian Autokorelasi

\begin{tabular}{lll}
\hline Hipotesis Nol & Keputusan & Jika \\
\hline Tidak ada autokorelasi positif & Tolak & $0<\mathrm{d}<\mathrm{dl}$ \\
Tidak ada autokorelasi positif & Tidak Ada Keputusan & $\mathrm{dl} \leq \mathrm{d} \leq \mathrm{du}$ \\
Tidak ada autokorelasi negatif & Tolak & $4-\mathrm{dl}<\mathrm{d}<4$ \\
Tidak ada autokorelasi negatif & Tidak Ada Keputusan & $4-\mathrm{du} \leq \mathrm{d} \leq 4-\mathrm{dl}$ \\
Tidak ada autokorelasi positif atau negatif & Tidak ditolak & $\mathrm{du}<\mathrm{d}<4-\mathrm{du}$ \\
\hline
\end{tabular}

Sumber : Gudjarati, (2009).

Nilai Durbin Watson hitung adalah 3,048 kemudian dimasukkan ke kriteria tidak ada autokorelasi positif atau negatif $1,546<\mathrm{d}<$ 2,454 maka tidak ada autokorelasi positif atau negatif pada model tidak ditolak. Berdasarkan hal tersebut, residual dari model regresi bebas dari autokorelasi positif atau negatif. Klasik menunjukkan bahwa model regresi yang diperoleh memenuhi asumsi normalitas dan asumsi klasik selanjutnya model akan diinterprestasi sesuai dengan urutan berikut ini.

R Square
Hasil pengujian Normalitas dan Uji Asumsi

Koefisien determinasi $\left(\mathrm{R}^{2}\right)$ adalah 0,942 yang menjelaskan bahwa variabel-variabel independen yaitu pertumbuhan produksi industry tekstil $\left(\mathrm{X}_{1}\right)$ dan sektor transportasi dan pergudangan (X2) mampu menentukan nilai ekspor industri tekstil sebesar 94,2 persen, sedangkan sisanya 5,8 persen dijelaskan variabel di luar model.

\section{Uji F}

Uji Simultan (F-test), disajikan pada Tabel 8, digunakan menguji secara simultan pengaruh pertumbuhan produksi sektor industry tekstil $\left(\mathrm{X}_{1}\right)$ dan sektor transportasi dan pergudangan (X2) terhadap ekspor industry tekstil.

Tabel 8. Hasil Uji Simultan

\begin{tabular}{lc}
\hline Keterangan & Nilai \\
\hline F-statistic & 40.660 \\
Prob(F-statistic) & 0.001 \\
\hline umber :BPS Jateng (2018) diolah.
\end{tabular}

Probabilitas F-statistik senilai 0.001lebih kecil dari nilai alfa 0,05 sehingga secara simultan pertumbuhan produksi sektor industri tekstil $\left(\mathrm{X}_{1}\right)$ dan sektor transportasi dan pergudangan (X2) mampu mempengaruhi ekspor industri tekstil.
Uji t

Uji parsial digunakan untuk menguji hipotesis masing-masing variabel independen terhadap variabel dependen di dalam model regresi. Tabel 9. Hasil pengujian hipotesis disajikan pada

Tabel 9. Uji Hipotesis

\begin{tabular}{llllc}
\hline Hipotesis & Koefisien & Sig. & $\begin{array}{l}\text { Keterangan } \\
\alpha=10 \%\end{array}$ & $\begin{array}{c}\text { Kesesuaian } \\
\text { Teori }\end{array}$ \\
\hline $\mathrm{H}_{1}: \beta_{1}>0$ & $-0,009$ & 0,840 & Tidak Signifikan: $\mathrm{H}_{1}$ ditolak, $\mathrm{H}_{0}$ diterima & - , tidak sesuai \\
$\mathrm{H}_{2}: \beta_{2}>0$ & 0,890 & 0,000 & Signifikan: $\mathrm{H}_{1}$ diterima, $\mathrm{H}_{0}$ ditolak & + , sesuai \\
\hline
\end{tabular}

Sumber :BPS Jateng (2018) diolah. 
Hasil uji t menunjukkan signifikansi pada tingkat keyakinan 95 persen bahwa :

1. Pertumbuhan produksi sektor industri berpengaruh negatif terhadap ekspor produk industri tekstil.

2. Sektor transportasi dan pergudangan berpengaruh positif terhadap ekspor produk industri tekstil.

Koefisien pengaruh regresi yang dijelaskan sebagai berikut :

a. $\beta 1=-0,009$ adalah nilai elastisitas pertambahan produksi indutri tekstil terhadap nilai ekspor produk tekstil. Artinya jika pertambahan produksi industri tekstil meningkat maka ekspor industri tekstil menurun. Dalam hal ini ada indikasi pertambahan produksi industri tekstil bukan disebabkan pertambahan peningkatan kapasitas produksi tetapi penekanan pada pemenuhan pesanan yang dimiliki dari periode waktu sebelumnya.

b. $\beta 2=0,890$ merupakan nilai elastisitas peningkatan layanan transportasi dan pergudangan berpengaruh positif terhadap nilai ekspor industri tekstil. Jika rata-rata layanan transportasi dan pergudangan meningkat 10 persen maka ekspor produk tekstil akan meningkat 8,9 persen. Hasil ini menunjukkan bahwa transportasi mendukung pergerakan dan pengiriman barang ekspor, sedangkan pergudangan mendukung pengelolaan inventori bahan baku dan produk jadi industri tekstil.

\section{SIMPULAN}

a. Industri tekstil merupakan penyumbang nilai ekspor utama di Jawa Tengah dengan kontribusi42,31 persen dari total ekspor pada tahun 2017.

b. Pertambahan produksi industri tekstil meningkat maka ekspor industri tekstil menurun. Dalam hal ini ada indikasi pertambahan produksi industri tekstil bukan disebabkan pertambahan peningkatan kapasitas produksi tetapi penekanan pada pemenuhan pesanan yang dimiliki dari periode waktu sebelumnya. c. Sektor transportasi dan pergudangan berpengaruh positif terhadap nilai ekspor produk tekstil di Jawa Tengah.

\section{DAFTAR PUSTAKA}

Badan Pusat Statistik (BPS) Jawa Tengah (Jateng). 2018. Statistik Ekspor Jawa Tengah 2010. http :https://jateng.bps.go.id.

Badan Pusat Statistik (BPS) Jawa Tengah (Jateng). 2018. Statistik Ekspor Jawa Tengah 2011. http :https://jateng.bps.go.id.

Badan Pusat Statistik (BPS) Jawa Tengah (Jateng). 2018. Statistik Ekspor Jawa Tengah 2012. http :https://jateng.bps.go.id.

Badan Pusat Statistik (BPS) Jawa Tengah (Jateng). 2018. Statistik Ekspor Jawa Tengah 2013. http :https://jateng.bps.go.id.

Badan Pusat Statistik (BPS) Jawa Tengah (Jateng). 2018. Statistik Ekspor Jawa Tengah 2014. http :https://jateng.bps.go.id.

Badan Pusat Statistik (BPS) Jawa Tengah (Jateng). 2018. Statistik Ekspor Jawa Tengah 2015. http :https://jateng.bps.go.id.

Badan Pusat Statistik (BPS) Jawa Tengah (Jateng). 2018. Statistik Ekspor Jawa Tengah 2016. http :https://jateng.bps.go.id.

Badan Pusat Statistik (BPS) Jawa Tengah (Jateng). 2018. Statistik Ekspor Jawa Tengah $2017 . \quad$ http :https://jateng.bps.go.id.

Badan Pusat Statistik (BPS) Jawa Tengah (Jateng). 2018. Produk Domestik Regional Bruto Jawa Tengah 2010. http :https://jateng.bps.go.id.

Badan Pusat Statistik (BPS) Jawa Tengah (Jateng). 2018. Produk Domestik Regional Bruto Jawa Tengah 2011. http :https://jateng.bps.go.id.

Badan Pusat Statistik (BPS) Jawa Tengah (Jateng). 2018. Produk Domestik 
Regional Bruto Jawa Tengah 2012. http :https://jateng.bps.go.id.

Badan Pusat Statistik (BPS) Jawa Tengah (Jateng). 2018. Produk Domestik Regional Bruto Jawa Tengah 2013. http :https://jateng.bps.go.id.

Badan Pusat Statistik (BPS) Jawa Tengah (Jateng). 2018. Produk Domestik Regional Bruto Jawa Tengah 2014. http :https://jateng.bps.go.id.

Badan Pusat Statistik (BPS) Jawa Tengah (Jateng). 2018. Produk Domestik Regional Bruto Jawa Tengah 2015. http :https://jateng.bps.go.id.

Badan Pusat Statistik (BPS) Jawa Tengah (Jateng). 2018. Produk Domestik Regional Bruto Jawa Tengah 2016. http :https://jateng.bps.go.id.

Badan Pusat Statistik (BPS) Jawa Tengah (Jateng). 2018. Produk Domestik Regional Bruto Jawa Tengah 2017. http :https://jateng.bps.go.id.

Badan Pusat Statistik (BPS) Jawa Tengah (Jateng). 2018. Produk Domestik Regional Bruto Jawa Tengah 2018. http :https://jateng.bps.go.id.

Blakely, Edward J., 1989. Planning Local Economic Development Theory and Practice, Sage Publications, London.

Chintia, Santi. 2008. Faktor-Faktor yang Mempengaruhi Permintaan Ekspor TPT Indonesia di Uni Eropa. Skripsi. Prodi Srudi Ekonmi Pertanian dan Sumberdaya. IPB.
Gudjarati, Damodar N. 2009. Basic Econometrics. Fifth Edition. Singapore:International Edition. McGraw-Hill.

Khairunnisa dan Septi. 2009. Analisis faktorFaktor yang Mempengaruhi Permintaan Ekspor Tekstil dan Produk Tekstil (TPT) Indonesia di Amerika Serikat. Repository.ipb.ac.id

Lincolin Arsyad, 1999. Pengantar Perencanaan dan pembangunan Ekonomi Daerah, BPFE, Yogyakarta.

Nugroho, Wakhid. 2011. Analisis FaktorFaktor yang Mempengaruhi Ekspor Tekstil Indonesia tahun 1985 - 2005. Eprints ums.ac.id.

Nugroho SBM, 2004. Model Basis Untuk Perencanaan Pembangunan Daerah. Dinamika Pembangunan Vol.1 No.1/Juli 2004 : 23-30, FE Undip, Semarang.

PT Pelindo III. (2015). Kiat TPKS Hadapi $M E A$ 2015. Diakses Oktober 2015,http://www.bumn.go.id/pelindo3/be rita/2448/Kiat.TPKS.Hadapi.MEA.2015

Setianto, W. 2014 . Analisis Faktor-Faktor yang Mempengaruhi Ekspor Tekstil Indonesia Periode 2007-2011. Economics Development Analysis Journal, Volume 3. No 1. 2014.

Yulyanti, 2002. Beberapa Faktor yang Mempengaruhi Volume Ekspor Tekstil INdonesia ke Amerika Serikat dan Jepang Periode 1980-2000. http://lib.unair.ac.id repository.unair.ac.id/47088 
Kurniani, dkk/AdBis 20 (1): 11 - 20 